\title{
Abnormal Membrane Fluidity as a Cause of Impaired Functional Dynamics of Chemoattractant Receptors on Neonatal Polymorphonuclear Leukocytes: Lack of Modulation of the Receptors by a Membrane Fluidizer
}

\author{
KOZO YASUI, MIDORI MASUDA, TAKAFUMI MATSUOKA, MUNEHIRO YAMAZAKI, \\ ATSUSHI KOMIYAMA, TARO AKABANE, MASAFUMI HASUI, YOHNOSUKE KOBAYASHI, AND \\ KENJIRO MURATA \\ Department of Pediatrics, Shinshu University School of Medicine, Matsumoto 390 and; Department of Pediatrics \\ [Y.K.] and Department of Clinico-laboratory Medicine [M.M., K.M.], Kansai Medical University, Moriguchi, \\ Osaka 570, Japan
}

\begin{abstract}
Membrane properties associated with chemoattractant-mediated cellular responsiveness of neonatal polymorphonuclear leukocytes (PMN) were analyzed using $\mathrm{n}$-formylmethionyl-leucyl-phenylalanine. Inasmuch as aliphatic alcohols as a membrane fluidizer can enhance the chemoattractant binding and affect subsequent cellular responsiveness in adult PMN, neonatal PMN were studied for such properties by their treatment with iso-propyl alcohol, an aliphatic alcohol. The alcohol $(<2.5 \%)$ treatment enhanced the $\mathbf{N}$-formylmethionyl-leucyl-phenylalanine binding to adult PMN, but there were no changes in the $\mathrm{N}$-formylmethionyl-leucyl-phenylalanine binding to neonatal PMN. Although the N-formylmethionyl-leucylphenylalanine-induced subsequent responsiveness including migration, lysosomal enzyme release and superoxide anion production were modulated by the alcohol treatment in adult PMN, there was no such modulation in neonatal PMN. Because membrane fluidity is largely involved in the regulation of the receptor functions, the membrane fluidity of neonatal PMN was next measured by an excimer-forming lipid technique in flow cytometry. The membrane fluidity value $(0.45 \pm 0.037)$ of neonatal PMN was lower than that $(0.74 \pm 0.072)$ of adult PMN $(p<0.01)$. Although the aliphatic alcohol enhanced the membrane fluidity of adult PMN, it did not affect the membrane fluidity of neonatal PMN. We conclude that there is abnormal membrane fluidity as a cause of impaired functional dynamics of the chemoattractant receptors, which appears to underlie the defective modulation of cell functions by the membrane fluidizer in neonatal PMN. (Pediatr Res 24: 442-446, 1988)
\end{abstract}

\section{Abbreviations}

PMN, polymorphonuclear leukocytes FMLP, N-formylmethionyl-leucyl-phenylalanine SOD, superoxide dismutase

$K_{D y}$ dissociation constant
In neonates, PMN are impaired in the chemotaxis (1-3) and are defective in the deformability and adhesiveness $(4,5)$. In addition, defective oxidative metabolism in neonatal PMN has been described by some investigators (6-9). These functional defects of PMN appear to be largely responsible for the hypersusceptibility to bacterial infections in neonates (10-12), and the precise mechanism for such a variety of functional defects awaits further investigations.

Synthetic N-formylated peptides such as FMLP induce a variety of neutrophil responses including chemotaxis, lysosomal enzyme secretion, and superoxide anion production (13). PMN chemotactic responses are initiated by the binding of the chemoattractant to its specific receptors on the cell membrane $(14,15)$. Chemoattractants at higher doses can also stimulate PMN to secrete lysosomal enzymes and produce superoxide anion (13). Such divergent alteration in the biologic activities to the same stimulant can be initiated by occupancy of the chemoattractant receptors that appears to be regulated by physical properties of the cell membrane (16).

Chemoattractant receptors for $\mathrm{N}$-formylated peptides exist in more than one affinity state and the receptor affinity reflects its functional activity (17). PMN can modulate the chemoattractant receptors in a dynamic fashion by changing the affinity of the binding sites depending upon the environment (18). There are many agents that can modulate the receptors in various ways (18). Of the agents, aliphatic alcohols can, as a membrane fluidizer, augment membrane fluidity and decrease membrane microviscosity of cells, affecting the chemoattractant accessibility of the receptors and biologic activities (19). The treatment of PMN with these alcohols leads to increases in their chemoattractant binding and the subsequent chemotactic responsiveness and decreases in their enzyme release and superoxide anion production $(19,20)$. Our studies were conducted to examine the modulation of the chemoattractant receptors of neonatal PMN by a membrane fluidizer. For the purpose, we have analyzed the membrane fluidizer-mediated modulation of the FMLP receptor binding, subsequent responsiveness such as chemotaxis, secretory function and respiratory burst, and membrane fluidity in neonatal PMN.

\section{MATERIALS AND METHODS}

Correspondence Kozo Yasui, Department of Pediatrics, Shinshu University School of Medicine, Asahi 3-1-1, Matsumoto 390, Japan.

Supported in part by grants-in-aid for encouragement of young scientist from the Japanese Ministry of Education, Culture and Science $(60772014,63770642)$. Cell preparation. Heparinized cord blood samples were ob-
tained from healthy full-term neonates. The neonates were of 
between 38 and 42 wk of gestation, of appropriate size for gestational age ( $\pm 2 \mathrm{SD}$ from the mean), and free of stress and asphyxia. PMN were isolated from the blood samples by a modification of the method of Böyum (21). The cells were washed twice with Dulbecco's phosphate-buffered saline (pH 7.4) and resuspended at appropriate concentrations in RPMI 1640 with $10 \%$ calf serum for motility assays and in the buffer for assays of chemoattractant receptors, secretory functions, respiratory burst, and membrane fluidity. They were used as neonatal PMN. For comparison, heparinized venous blood samples were drawn from normal infants (1-8 months of age), children (1-6 years old) and healthy adults, and PMN suspensions were prepared in the same fashion as described above; they were used as infant, child, and adult PMN, respectively. The purity of PMN was more than $95 \%$ as judged by Giemsa stain smears. For some experiments, neonatal and adult lymphocytes were prepared from the heparinized blood samples by the conventional FicollHypaque density centrifugation.

Treatment of PMN with aliphatic alcohol. PMN were incubated with various concentrations of iso-propyl alcohol, an aliphatic alcohol, at $25^{\circ} \mathrm{C}$ for $30 \mathrm{~min}$. After the incubation, the cells were assayed for the FMLP binding, FMLP-induced cellular functions, and membrane fluidity. The alcohol was persistently present during the assays.

Assay of ${ }^{3} H-F M L P$ binding to PMN. ${ }^{3} \mathrm{H}-\mathrm{FMLP}$, with specific activity $49.4 \mathrm{Ci} / \mathrm{mmol}$, was purchased from New England Nuclear (Boston, MA). The FMLP binding was assayed by a modification of the method of Snyderman and Fudman (22) as previously reported (23). The binding of ${ }^{3} \mathrm{H}$-FMLP was carried out with $1.5 \times 10^{6}$ cells in $0.15 \mathrm{ml}$ in the absence (total binding) and presence (nonspecific binding) of 1000 -fold unlabeled FMLP at $25^{\circ} \mathrm{C}$ for $30 \mathrm{~min}$. The specific binding was defined as the total binding minus the nonspecific binding. Each experiment was done in duplicate or triplicate. SE of the binding were less than $5 \%$ in all cases.

Assay of motility. PMN motility was measured by the agarose plate method (24) using $10^{-8}$ M FMLP (Sigma Chemical Co., St. Louis, MO). The center well on the plate received a $10 \mu \mathrm{l}$ volume of cell suspension containing $1.0 \times 10^{8} / \mathrm{ml}$ PMN untreated or treated with isopropyl alcohol, and the outer and inner wells received an equal volume of a chemoattractant and nonchemotactic culture medium, respectively. After the incubation at $37^{\circ}$ $\mathrm{C}$ for $3 \mathrm{~h}$, migration was evaluated by measurement of linear distance in the direction for the chemoattractant (chemotaxis) compared with those for control medium (random migration). The values were represented as migration distance $(\times 0.3 \mathrm{~mm})$.

Assay of lysosomal enzyme secretion by PMN. PMN were suspended at $2.0 \times 10^{6} / \mathrm{ml}$ in the buffer and incubated for 30 min in the absence or presence of isopropyl alcohol. The PMN suspension was then incubated at $37^{\circ} \mathrm{C}$ with cytochalasin $\mathrm{B}$ (10 $\mu \mathrm{M})$ for $15 \mathrm{~min}$ and then cultured for another $15 \mathrm{~min}$ with addition of FMLP $(1 \mu \mathrm{M})$. The reaction was terminated by immersion in an ice bath followed by centrifugation. Supernatants were assayed for lysozyme and $\beta$-glucuronidase activities by the methods previously described (25).

Assay of superoxide anion release by PMN. Superoxide anion was measured by the determination of SOD-inhibitable ferricytochrome c (Sigma) reduction assay (9). Cells were suspended at $1.0 \times 10^{6} / \mathrm{ml}$ in the buffer and preincubated for $30 \mathrm{~min}$ in the absence or presence of isopropyl alcohol. The total volume of all reaction mixtures was $1 \mathrm{ml}$; they contained $100 \mu \mathrm{l}$ of PMN suspension $\left(1.0 \times 10^{7} / \mathrm{ml}\right), 50 \mu \mathrm{l}$ of $2 \mathrm{mM}$ ferricytochrome $\mathrm{c}$, and $25 \mu \mathrm{l}$ of buffer (sample tube) or SOD (reference tube). After the reaction mixture was temperature equilibrated $\left(37^{\circ} \mathrm{C}\right)$, the reaction was started by adding stimuli (FMLP; $10^{-7} \mathrm{M}$ ). After incubation for $6 \mathrm{~min}$, the tubes were immersed in an ice bath and centrifuged. Supernatants of duplicate samples were assayed spectrophotometrically at $550 \mathrm{~nm}$; absorbance was converted to nanomoles of cytochrome $\mathrm{c}$ reduced (nmol O$--10^{6} \mathrm{PMN}$ ), which was determined by using a molar extinction coefficient of $21 \times$ $10^{3} / \mathrm{cm} / \mathrm{mol} /$ liter.
Assay of membrane fluidity. The membrane fluidity was measured according to the method described previously (26), which was the excimer-forming lipid technique introduced into the flow cytometry using bandpass filters. PMN treated with isopropyl alcohol and lymphocytes were fluorescently labeled by incubating them with $15 \mu \mathrm{M}$ pyrenedecanoic acid (Molecular Probes) for $15 \mathrm{~min}$ at $25^{\circ} \mathrm{C}$, and then they were applied to flow cytometry. Fluorescence intensity of monomer and excimer pyrenedecanoic acid was determined by a flow cytometer (FACS III; Becton Dickinson, Sunnyvale, CA) equipped with a $5 \mathrm{~W}$ argon ion laser (360 $\mathrm{nm}$ emission, $20 \mathrm{~mW}$ output) and bandpass filters of 400 and $450 \mathrm{~nm}\left(70 \mathrm{~nm}\right.$ bandwidth). At least $1 \times 10^{4}$ cells were examined in each sample. Membrane fluidity was expressed as a fluorescence intensity ratio of excimer to monomer pyrenedecanoic acid $\left(I_{E} / I_{M}\right.$ ratio), which was calculated by the following expression:

$$
\begin{aligned}
& \text { total of [channel number }(450 \mathrm{~nm}) \\
& \times \text { PMN count on each channel] } \\
& \frac{\text { total of [channel number }(400 \mathrm{~nm})}{\times \text { PMN count on each channel] }}
\end{aligned}
$$

Assay of PMN volume. The volume of PMN was determined by comparing the forward light scatter on a flow cytometer (FACS III).

Statistical analysis. Statistical significance of differences between groups was performed using Student's $t$ test. A $p$ value of $<0.05$ was considered significant in all cases.

\section{RESULTS}

Saturability of ${ }^{3} \mathrm{H}-F M L P$ binding sites on $P M N$. The specific bindings of 3.3-50 nM ${ }^{3} \mathrm{H}-\mathrm{FMLP}$ to neonatal, infant, child, and adult PMN (30 min, $25^{\circ} \mathrm{C}$ ) were obtained. Interpretation of ligand binding by living cells must be made with caution because the cell-associated radioactivity represents the sum of binding, internalization, and degradation. With this caution in mind, we attempted to calculate a $\mathrm{K}_{\mathrm{D}}$ and binding sites/per cell in every case; the $\mathrm{K}_{\mathrm{D}}$ of neonatal PMN $(n=10)$ was $22.40 \pm 2.91 \mathrm{nM}$ with $53,800 \pm 7,000$ receptors/cell as compared with that of infant PMN $(n=8)$, child PMN $(n=10)$, and adult PMN $(n=$ 10) of $24.50 \pm 3.35 \mathrm{nM}$ with $55,000 \pm 3,000$ receptors/cell, $25.52 \pm 4.50 \mathrm{nM}$ with $52,000 \pm 6,000$, and $25.60 \pm 3.59 \mathrm{nM}$ with $53,300 \pm 6,000$ receptors/cell, respectively. There were no statistical differences in the number and dissociation constant of FMLP binding sites/cell between any pair of the PMN samples.

The effect of isopropyl alcohol on the ${ }^{3} \mathrm{H}-\mathrm{FMLP}$ binding to PMN was tested. Figure 1 shows the results of the ${ }^{3} \mathrm{H}-F M L P$ binding to neonatal PMN and adult PMN pretreated with the alcohol at $25^{\circ} \mathrm{C}$ for $30 \mathrm{~min}$. In the control experiments, isopropyl alcohol enhanced the FMLP binding to adult PMN incubated with lower concentrations of ${ }^{3} \mathrm{H}-\mathrm{FMLP}$ : the specific binding reached equilibrium at a lower concentration of ${ }^{3} \mathrm{H}-\mathrm{FMLP}(n=$ 5 ), and its binding to adult PMN exposed to $2.5 \%$ iso-propyl alcohol was augmented to 2.4-fold of that to the control cells without the alcohol treatment at $10 \mathrm{nM}{ }^{3} \mathrm{H}-\mathrm{FMLP}$. In contrast, there were no such changes in the ${ }^{3} \mathrm{H}$-FMLP specific binding to neonatal PMN $(n=5)$. In the comparative experiments, there was the isopropyl alcohol enhancement of the ${ }^{3} \mathrm{H}$-FMLP binding in child PMN but not in infant PMN (data not shown).

Motility of $P M N$. Random migration and chemotaxis under agarose of neonatal PMN were assessed in 15 newborns, comparing with those of infant PMN $(n=8)$, child PMN $(n=10)$, and adult PMN $(n=15)$. Random migration of neonatal PMN was normal. The migration value (mean $\pm \mathrm{SD}$ ) was $4.82 \pm 0.28$ as compared to the adult value of $5.05 \pm 0.42(p=0.1)$; the values was not different from those of infant PMN $(4.75 \pm 0.35)$ and child PMN (4.95 \pm 0.46$)$. Chemotaxis of neonatal PMN was defective; the migration value was $8.14 \pm 0.48$ as compared to the adult value of $11.49 \pm 1.01(p<0.01)$. For comparison, chemotaxis of infant PMN $(8.75 \pm 0.95, p<0.01)$ was also 
a

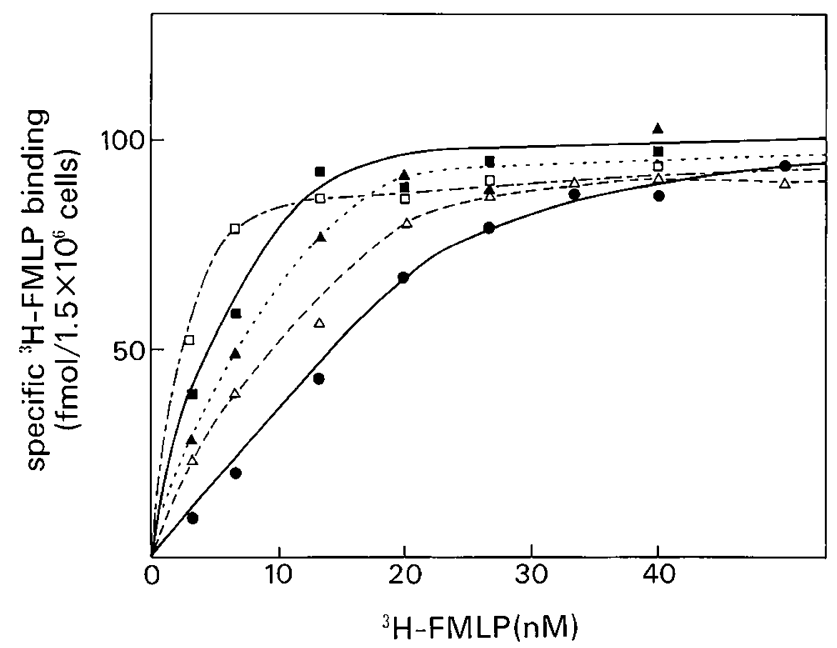

b

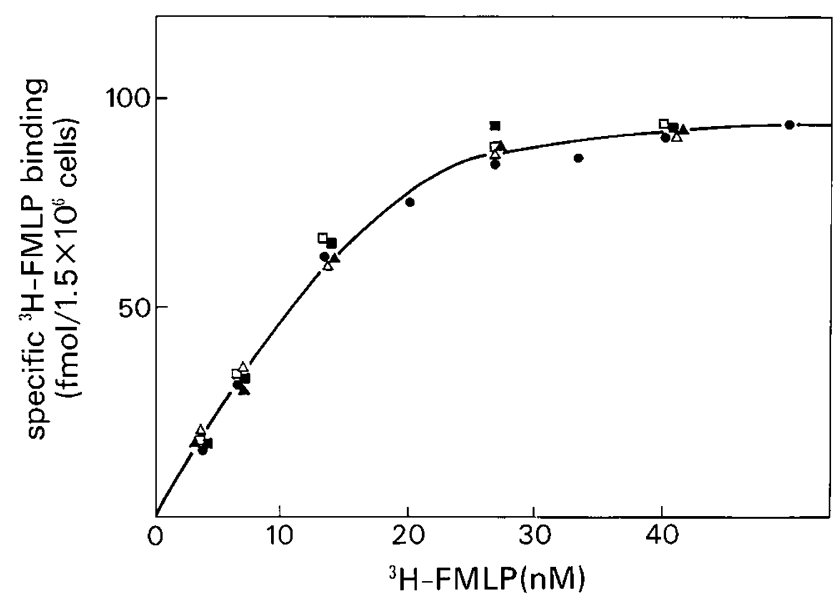

Fig. 1. Specific binding of ${ }^{3} \mathrm{H}-\mathrm{FMLP}$ to adult $(a)$ and neonatal PMN $(b)$ untreated $(\bullet)$ or treated with $0.5 \%(\triangle), 1.5 \%(\boldsymbol{\Delta}), 2.5 \%(\square)$, and $5.0 \%$ (ם) isopropyl alcohol. Paired Student's $t$ tests of the data obtained from five duplicated experiments revealed no significant difference.

defective, but that of child PMN $(10.75 \pm 1.25, p=0.75)$ was normal as compared to the adult PMN value.

Chemotaxis of neonatal, infant, child, and adult PMN was further analyzed by their treatment with isopropyl alcohol (Fig. $2)$. The peak chemotactic response of adult PMN $(n=5)$ was elevated by their treatment with low concentrations of isopropyl alcohol: the value increased from $9.80 \pm 0.42$ without treatment to $12.52 \pm 0.35$ with $2.5 \%$ alcohol treatment $(p<0.01)$. In contrast, there was no change in the chemotactic response of neonatal PMN $(n=5)$ when treated with equal concentrations of the alcohol. The random migration was not affected by the alcohol treatment in each sample. The inhibition of PMN chemotaxis by higher concentrations of isopropyl alcohol $(>5.0 \%)$ was presumably due to the dose dependent cellular toxicity of the alcohol.

Lysosomal enzyme secretion by PMN. Neonatal PMN released normal amounts of lysozyme and $\beta$-glucuronidase activities as compared to the respective adult values (Table 1). The alcohol treatment decreased the release of both lysosomal enzymes by adult PMN, but it did not change that by neonatal PMN.

Superoxide anion production by $P M N$. The $\mathrm{O}_{2}^{-}$production by neonatal and adult PMN was examined and the results are shown in Figure 3. Neonatal PMN produced $13.4 \pm 1.3 \mathrm{nmol} \mathrm{O}_{2}^{-} / 10^{6}$ cells $/ 6 \mathrm{~min}$ as compared to the adult value of $11.8 \pm 2.0 \mathrm{nmol}$ $\mathrm{O}_{2}^{-} / 10^{6}$ cells $/ 6 \mathrm{~min}$. The alcohol treatment yielded dose-depend-



Fig. 2. Dose-dependent effect of isopropyl alcohol on FMLP-stimulated chemotaxis of neonatal PMN $(O)$, infant $\operatorname{PMN}(\triangle)$, child $\operatorname{PMN}(\boldsymbol{\Delta})$, and adult PMN (@). Cells were incubated with the alcohol at $25^{\circ} \mathrm{C}$ for $30 \mathrm{~min}$ and then applied to chemotaxis assay under agarose. Migration values represent the migration distance $(\times 0.3 \mathrm{~mm})$. Results represent means \pm SD of five independent determinations.

Table 1. Effect of alcohol on lysosomal enzyme release by neonatal and adult PMN*

\begin{tabular}{|c|c|c|c|c|}
\hline \multirow{3}{*}{$\begin{array}{c}\text { Alcohol } \\
(\%)\end{array}$} & \multicolumn{4}{|c|}{$\%$ release of enzymes contained by cells } \\
\hline & Adult PMN & & Neonatal PMN & \\
\hline & lysozyme & $\beta$-glucuronidase & lysozyme & $\beta$-glucuronidase \\
\hline 0 & $40 \pm 10$ & $22 \pm 5$ & $38 \pm 7$ & $24 \pm 5$ \\
\hline 1.0 & 32 & 18 & 38 & $22 \pm 4$ \\
\hline 2.5 & $21 \pm$ & $16 \pm$ & $33 \pm 6$ & $28 \pm 7$ \\
\hline 5.0 & $15 \pm 5 \dagger$ & $12 \pm 3 \dagger$ & $35 \pm 9$ & $21 \pm 4$ \\
\hline
\end{tabular}

* Results represent mean \pm SD of five samples.

$\dagger p<0.05$ control experiment versus alcohol treatment.

ent depression of the $\mathrm{O}_{2}^{-}$production by adult PMN, whereas the treatment with lower concentrations of the alcohol $(<2.5 \%)$ had no significant effect on the function of neonatal PMN.

Membrane fluidity of PMN. Table 2 shows results of the membrane fluidity as $\mathrm{I}_{\mathrm{E}} / \mathrm{I}_{\mathrm{M}}$ ratios of neonatal, infant, child, and adult PMN and the effect of iso-propyl alcohol on the fluidity. The $I_{E} / I_{M}$ ratio of neonatal $P M N$ was lower than that of adult PMN; the ratio was also lower than the values of infant and child PMN. To examine the alcohol effect, PMN were treated with $1.0-5.0 \%$ isopropyl alcohol for $30 \mathrm{~min}$ at $25^{\circ} \mathrm{C}$ and processed for measuring the fluorescence intensity. Although the $I_{E} / I_{M}$ ratios of infant, child, and adult PMN increased with increasing concentrations of the alcohol, that of neonatal PMN did not change by the alcohol treatment. In a comparative experiment, neonatal lymphocytes were studied for the membrane fluidity. The $\mathrm{I}_{\mathrm{E}} / \mathrm{I}_{\mathrm{M}}$ ratio of neonatal lymphocytes $(0.365 \pm 0.117, n=6)$ was lower than that of adult lymphocytes $(0.644 \pm 0.036, n=6$, $p<0.01)$.

Volume of PMN. When examined by comparing the forward light scatter on a flow cytometer, there was no difference in the cell distribution between neonatal PMN and adult PMN.

\section{DISCUSSION}

The chemoattractant-induced cellular responses are initiated by the binding of a chemoattractant to its specific cell surface receptors $(14,15)$. In analyzing abnormalities in the chemoattractant-induced functions of neonatal PMN, it is of importance to learn the nature of interaction of a chemoattractant with its membrane receptors. We measured here the isothermal ${ }^{3} \mathrm{H}$ - 
FMLP binding by neonatal PMN, but failed to demonstrate the abnormal binding of the chemoattractant by the cells. In fact, neonatal PMN were normal in the receptor numbers and binding affinity of the chemoattractant receptors, and this was inconsistent with the previous reports $(27,28)$.

In recent years, attention has been focused on the dynamic nature of formyl peptide chemoattractant receptors on PMN membrane. PMN can modulate the expression of the chemoattractant receptors by increasing or decreasing the affinity of the binding sites, depending on their environment (18). The modulation of the receptors plays an important role in controlling the subsequent PMN responsiveness such as chemotaxis, secretory functions, and respiratory burst. It still remains unknown if the dynamic modulation of FMLP receptors can occur in a normal fashion in neonatal PMN.

Plasma membrane fluidity affects the degree of exposure of receptor proteins and the accessibility of receptors $(29,30)$. Therefore, membrane fluidity is largely involved in the modulation of the chemoattractant receptors and the subsequent cellular responsiveness (31). In this regard, aliphatic alcohols can change cell rigidity and decrease the membrane microviscosity through alteration of lipid fluidity of the membrane (19), resulting in an increase in the membrane fluidity. The alcohol-induced increase in PMN membrane fluidity is accompanied by augmentation of the affinity level of chemoattractant receptors followed by an increase in the cell motility and a decrease in the lysosomal enzyme release and superoxide anion production (19).

In our studies, although the alcohol $(<2.5 \%)$ treatment enhanced the FMLP binding to adult PMN, there were no changes

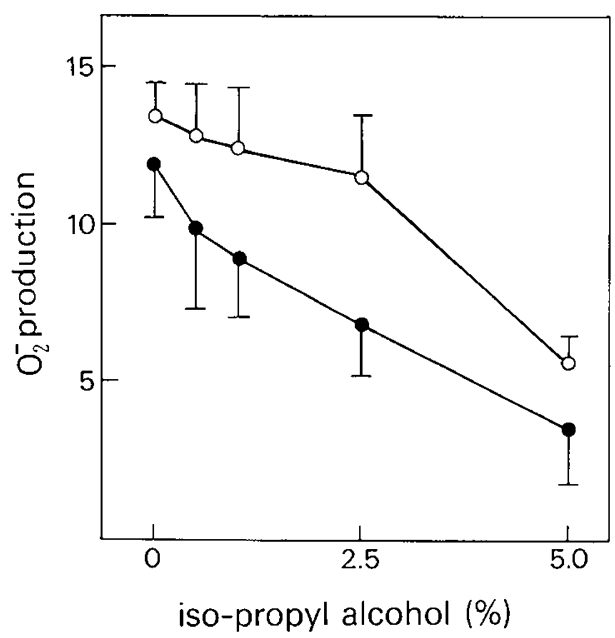

Fig. 3. Dose-dependent effect of isopropyl alcohol on superoxide anion production by neonatal PMN $(\mathrm{O})$ and adult PMN $(\bullet)$. Cells were incubated at $25^{\circ} \mathrm{C}$ for $30 \mathrm{~min}$ and then applied to superoxide anion production assay. Results represent means $\pm \mathrm{SD}$ of five independent determinations. The values represent $\mathrm{nmol} \mathrm{O}_{2}^{-} / 10^{6}$ cells $/ 6 \mathrm{~min}$. in the FMLP binding to neonatal PMN. In this respect, similar results were obtained with another membrane fluidizer, butanol (data not shown). Such failure in enhancing the accessibility of FMLP receptors by isopropyl alcohol indicates that the functional modulation of the receptors by the membrane fluidizer is impaired in neonatal PMN. Based on these results, we thought that the alcohol treatment may not change the FMLP-mediated subsequent cellular functions in neonatal PMN and this was indeed the case. In adult PMN, the higher accessibility state of the receptors induced by the alcohol was efficient in the enhancement of chemotaxis but adversely led to the depression of the receptor-mediating enzyme secretion or superoxide anion production. However, there was no such functional changes in neonatal PMN. These results certainly provide evidence that the dynamic modulation by the membrane fluidizer of the chemoattractant receptors is impaired, resulting in the failure in controlling the subsequent cellular responsiveness.

Inasmuch as membrane fluidity is largely involved in the modulation of the chemoattractant receptor functions (31) as described above, we next measured the membrane fluidity of PMN and examined its changes by isopropyl alcohol using an excimer-forming lipid technique in flow cytometry (26). The low $\mathrm{I}_{\mathrm{E}} / \mathrm{I}_{\mathrm{M}}$ ratio of neonatal $\mathrm{PMN}$ demonstrated a decrease in their membrane fluidity levels. The treatment with low concentrations of isopropyl alcohol increased the membrane fluidity of adult PMN, but did not change that of neonatal PMN. It is likely, therefore, that the abnormal membrane fluidity largely contributes to the impaired functional dynamics of FMLP receptors in neonatal PMN. In this regard, membrane fluidity of neonatal lymphocytes was also decreased, which is inconsistent with the previous work (30). These findings indicate that the abnormal membrane fluidity is not a selective defect for PMN in neonates. A cholesterol/phospholipid ratio markedly affects membrane fluidity and cellular rigidity (32). Any quantitative change in membrane lipid composition of neonatal leukocytes may contribute to these phenomena. More detailed information, however, will be needed concerning this matter.

PMN provide an effective host defense against bacterial infections. In the defense process, PMN first migrate to the sites of inflammation by their chemotactic ability. Once they reach these sites, PMN stop the chemotactic migration and release lysosomal enzymes and produce superoxide anion after ingesting the invading microorganisms. Discrete signals for different biologic responses to the same stimulant appear to be generated by the particular transduction unit to which the receptors are linked. In this respect, neonatal PMN are impaired in the dynamic functions of chemoattractant receptors, which may result in the failure in controlling the chemoattractant-mediated subsequent cellular functions. This may explain the paradox of abnormal cell functions in the presence of normal numbers of chemoattractant receptors in neonatal PMN. Such a defect of the membrane properties of neonatal PMN appears to be related with abnormal cell functions, leading to the increased susceptibility to bacterial infections in neonates. The membrane fluidity of PMN was still

Table 2. Effect of isopropyl alcohol on membrane fluidity of $P M N^{a}$

\begin{tabular}{ccccc}
\hline & \multicolumn{4}{c}{ Membrane fluidity $\left(\mathrm{I}_{\mathrm{E}} / \mathrm{I}_{\mathrm{M}}\right.$ ratio $)$} \\
\cline { 2 - 5 } $\begin{array}{c}\text { Alcohol } \\
(\%)\end{array}$ & $\begin{array}{c}\text { Adult PMN } \\
(n=6)\end{array}$ & $\begin{array}{c}\text { Child PMN } \\
(n=5)\end{array}$ & $\begin{array}{c}\text { Infant PMN } \\
(n=6)\end{array}$ & $\begin{array}{c}\text { Neonatal PMN } \\
(n=6)\end{array}$ \\
\hline 0 & $0.74 \pm 0.072 \dagger$ & $0.62 \pm 0.062 \dagger \ddagger$ & $0.58 \pm 0.081 \dagger \ddagger$ & $0.45 \pm 0.037 \ddagger$ \\
1.0 & $0.86 \pm 0.104 \S$ & $0.71 \pm 0.057 \S$ & $0.62 \pm 0.070$ & $0.47 \pm 0.054$ \\
2.5 & $0.96 \pm 0.153 \|$ & $0.75 \pm 0.063 \|$ & $0.66 \pm 0.090$ & $0.48 \pm 0.068$ \\
5.0 & $1.16 \pm 0.251 \|$ & $0.83 \pm 0.080 \|$ & $0.69 \pm 0.129 \S$ & $0.43 \pm 0.082$ \\
\hline
\end{tabular}

\footnotetext{
${ }^{a}$ Results represent mean \pm SD of five or six samples.

$\dagger p<0.01$ significantly different from neonatal PMN.

$\ddagger p<0.01$ significantly different from adult PMN.

$\S p<0.05$ control experiment versus alcohol treatment.

$\| p<0.01$ control experiment versus alcohol treatment.
} 
decreased during infancy and early childhood, although it was increased compared to that of neonatal PMN, which may be related to the development of PMN functions during the early period of life.

\section{REFERENCES}

1. Miller ME 1971 Chemotactic function in the human neonate: humoral and cellular aspects. Pediatr Res 5:487-492

2. Klein RB, Fisher TJ, Gard SE, Biberstein M, Rich KC, Stiehm ER 1977 Decreased mononuclear and polymorphonuclear chemotaxis in human newborns, infants, and young children. Pediatrics 60:467-472

3. Laurenti F, Ferro R, Marzetti G, Rossini M, Bucci G 1980 Neutrophil chemotaxis in preterm infants with infections. J Pediatr 96:468-470

4. Miller ME 1975 Developmental maturation of human neutrophil motility and its relationship to membrane deformability. In: Bellanti JA, Dayton DH (eds) The Phagocytic Cell in Host Resistance. Raven Press, New York, pp 295-307

5. Krause PJ, Herson VC, Boutin-Lebowitz J, Eisenfeld L, Block C, Lobello T, Maderaso EG 1986 Polymorphonuclear leukocyte adherence and chemotaxis in stressed and healthy neonates. Pediatr Res 20:296-300

6. Ambruso DR, Altenburger KM, Johnston RB Jr 1979 Defective oxidative metabolism in newborn neutrophils: discrepancy between superoxide anion and hydroxyl radical generation. Pediatrics 64(suppl):722-725

7. Shigeoka AO, Charette RP, Wyman ML, Hill HR 1981 Defective oxidative metabolic responses of neutrophils from stressed neonates. J Pediatr 98:392398

8. Strauss RG, Snyder EL 1983 Activation and activity of the superoxidegenerating system of neutrophils from human infants. Pediatr Res 17:662664

9. Yamazaki M, Matsuoka T, Yasui K, Komiyama A, Akabane T 1988 Increased production of superoxide anion by neonatal polymorphonuclear leukocytes stimulated with a chemotactic peptide. Am J Hematol 27:169-173

10. Quie PG, Cates KL 1978 Clinical manifestations of disorders of neutrophil chemotaxis. In: Gallin JI, Quie PG (eds) Leukocyte Chemotaxis. Raven Press, New York, pp 307-328

11. Wilson CB 1986 Immunologic basis for increased susceptibility of the neonate to infection. J Pediatr 108:1-12

12. Hill HR 1987 Biochemical, structural, and functional abnormalities of polymorphonuclear leukocytes in the neonate. Pediatr Res 22:375-382

13. Snyderman R, Goetzl EJ 1981 Molecular and cellular mechanisms of leukocyte chemotaxis. Science 213:830-837

14. Aswanikumar S, Corcoran B, Schiffman E, Day AR, Freer RJ, Showell HJ, Becker EL 1977 Demonstration of a receptor on rabbit neutrophils for chemotactic peptides. Biochem Biophys Res Commun 74:810-817

15. Williams LT, Snyderman R, Pike MC, Lefkowitz RJ 1977 Specific receptor sites for chemotactic peptides on human polymorphonuclear leukocytes. Proc Natl Acad Sci USA 74:1204-1208
16. Seligmann BE, Fletcher MP, Gallin JI 1982 Adaptation of human neutrophil responsiveness to the chemoattractant $\mathrm{N}$-formylmethionylleucylphenylalanine. J Biol Chem 257:6280-6286

17. Koo C, Lefkowitz RJ, Snyderman R 1982 The oligopeptide chemotactic factor receptor on human polymorphonuclear leukocyte membranes exists in two affinity states. Biochem Biophys Res Commun 106:442-449

18. Fletcher MP, Gallin JI 1983 Modulation of PMN receptors for chemotactic peptides. Surv Immunol Res 2:139-144

19. Yuli I, Tomonaga A, Snyderman R 1982 Chemoattractant receptor functions in human polymorphonuclear leukocytes are divergently altered by membrane fluidizers. Proc Natl Acad Sci USA 79:5906-5910

20. Pike MC, Jakoi L, Mcphail LC, Snyderman R 1986 Chemoattractant-mediated stimulation of the respiratory burst in human polymorphonuclear leukocytes may require appearance of protein kinase activity in the cell's particulate fraction. Blood 67:909-913

21. Böyum A 1968 Separation of leukocytes from blood and bone marrow. Scand J Clin Lab Invest 21 (suppl 97):77-89

22. Snyderman R, Fudman EJ 1980 Demonstration of a chemotactic factor receptor on macrophages. J Immunol 124:2754-2757

23. Yasui K, Yamazaki M, Miyagawa Y, Komiyama A, Akabane $\Upsilon 1987$ Decreased numbers of chemotactic factor receptors in chronic neutropenia with defective chemotaxis: spontaneous recovery from the neutrophil abnormalities during early childhood. Am J Hematol 25:67-75

24. Nelson RD, Quie PG, Simmons RL 1975 Chemotaxis under agarose: a new and simple method for measuring chemotaxis and spontaneous migration of human polymorphonuclear leukocytes and monocytes. J Immuno 115:1650-1656

25. Suzuki K, Swenson C, Sasagawa S, Sakatani T, Watanabe M, Kobayashi M, Fujikura T 1983 Age-related decline in lysosomal enzyme release from polymorphonuclear leukocytes after $\mathrm{N}$-formyl-methionyl-leucyl-phenylalanine stimulation. Exp Hematol 11:1005-1013

26. Masuda M, Kuriki H, Komiyama Y, Nishikado H, Egawa H, Murata K 1987 Measurement of membrane fluidity of polymorphonuclear leukocytes by flow cytometry. J Immunol Methods 96:225-231

27. Anderson DC, Hughes BJ, Smith CW 1981 Abnormal mobility of neonatal polymorphonuclear leukocytes: Relationship to impaired redistribution of surface adhesion sites by chemotactic factor or colchicine. J Clin Invest 68:863-874

28. Strauss RG, Snyder EL 1984 Chemotactic peptide binding by intact neutrophils from human neonates. Pediatr Res 18:63-66

29. Heron DS, Shinitzky M, Hershkowitz M, Samuel D 1980 Lipid fluidity markedly modulates the binding of serotonin to mouse brain membranes. Proc Natl Acad Sci USA 77:7463-7467

30. Neufeld ND, Corbo LM 1984 Membrane fluid properties of cord blood mononuclear leucocytes: association with increased insulin receptors. Pediat Res 18:773-778

31. Gallin JI, Seligmann BE 1984 Mobilization and adaptation of human neutrophil chemoattractant fmet-leu-phe receptors. Federation Proc 43:2732-2736

32. Shinitzky M, Henkart P 1979 Fluidity of cell membranes-current concepts and trends. Int Rev Cytol 60:121-147 